\title{
Study on the Rationality of Utilitarian Philosophy of Law-An Analysis
}

\section{Pradeep M. D.}

Research Scholar, School of Law, Alliance University, Bengaluru \& Assistant Professor, College of Social Sciences \& Humanities, Srinivas University, Mangaluru, Karnataka, India.

Email: mdpradeepnair767@gmail.com

Type of the Paper: Conceptual Analysis.

Type of Review: Peer Reviewed.

Indexed In: OpenAIRE.

DOI: https://doi.org/10.5281/zenodo.1491398.

Google Scholar Citation: $\underline{\text { IJCSBE }}$

\section{How to Cite this Paper:}

Pradeep, M. D. (2018). Study on the Rationality of Utilitarian Philosophy of Law-An Analysis. International Journal of Case Studies in Business, IT and Education (IJCSBE), 2(2), 77-85. DOI: https://doi.org/10.5281/zenodo.1491398.

International Journal of Case Studies in Business, IT and Education (IJCSBE)

A Refereed International Journal of Srinivas University, India.

(C) With Authors.

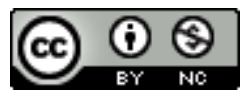

This work is licensed under a Creative Commons Attribution-Non Commercial 4.0 International License subject to proper citation to the publication source of the work.

Disclaimer: The scholarly papers as reviewed and published by the Srinivas Publications (S.P.), India are the views and opinions of their respective authors and are not the views or opinions of the S.P. The S.P. disclaims of any harm or loss caused due to the published content to any party. 


\title{
Study on the Rationality of Utilitarian Philosophy of Law- An Analysis
}

\author{
Pradeep M. D. \\ Research Scholar, School of Law, Alliance University, Bengaluru \& Assistant Professor, \\ College of Social Sciences \& Humanities, Srinivas University, Mangaluru, Karnataka, India. \\ Email: mdpradeepnair767@gmail.com
}

\begin{abstract}
The modern doctrine of sovereignty is derived basically from two thoughts of development which emerged during the end of Indian medieval history. On the one side there was an emergence of new National States which are curious enough to assert their absolute independence during the new age of economic expansion by rejecting the feudal notions including exaggerated lordship or papal interference and on the other side, the departure from medieval idea of law based on fundamental customs and legislations as a form of declaring the existence of new customs. The Utilitarian Philosophy is based on the consequential ideology of rightness or wrongness of any action is determined through the good and bad consequences of that act. Bentham developed a liberal theory of justice based on egalitarian principles in order to secure the life of the people in cooperation with each other. The new approach based on secularist and positivism even when the lip services are notionally subjected to override the natural law. Positivism flourishes in stable social conditions highlighting the difficulties involved in maintaining a rigid separation between 'what is' and 'what ought to be' are only projected to the forefront when conditions are critical. The theory and principles work as a manual of instructions to the legislators. This paper analyses the rationality of Utilitarian philosophy in terms of its feasibility and adequateness of law to attain welfare society.
\end{abstract}

Keywords: Sovereignty, State, Secularist, Natural law, Theory.

\section{INTRODUCTION :}

Each national territory is recognized to constitute both a self-sufficient unit and an independent legal entity with an understanding that, within each such nation-state, there exist some supreme power, where the decisive feature with the virtually unlimited capacity to make new laws. The new doctrine was the reassertion of the earlier theory in the form of 'Rex Est Imperator in Regno Suo' a maxim employed by the French lawyers in the fourteenth century to resist imperial pretension [1]. Hume stated that empiricism includes the rejection of natural law as a system of norms as the validity of normative rules cannot be logically considered to be an objective fact, but depends on the relative viewpoint of those who apply them [2]. On the other hand, Positive law considering as the law of the state, is ascertainable and valid without regarding to the subjective consideration. Hence it must be separated from the morals although it might correspond in many respects to current moral standards subjected to its influence.

\section{SOCIOLOGY OF LAW :}

The theory is truly considered to be the classic under the Sociology of Law. Classic describes themes, issues and conclusions on the future enquiries and provide information to enrich the knowledge [3]. In the Sociological Jurisprudence, Bentham's works on Theory \& Principles facilitates a new beginning by identifying base for many ideas and issues. The Bentham's theory depicts that, the object of Government and Law is to aim at maximum happiness of the community or the happiness of the whole society by highlighting the relationship between Law and Society [4]. The Theory 
elaborates on the truth that law is an instrument of social stability and works as an agent for social change [5]. Human beings lead based on the pains, motives, sensibilities, dispositions and expectations on one's life. The law should be founded to regulate the attributes otherwise cause it to be less useful. The law shall precisely a collaboration of both morals and legislations. It is a state of mental journey involving with the disengagement of oneself from local and national prejudices based on the adoptability of other communities. The Theory that, the demonstration of confused or dogmatic thinking about injustice or evils of the world will never provide resource for better human life always remain true with the essence of virtual clarity and coherence over analysis.

\section{HISTORICAL ANALYSIS :}

The initial phase of nineteenth century marked the beginning of the Positivist Movement by exposing a reaction to the existing methods of thinking prevailing in the preceding period. The theories of natural law depicted the feature of moving away from realities of actual law to discover reasonable principles of universal validity. The Bentham's social facts are manifested in his harsh attack on the natural law and natural rights. The modern doctrine of sovereignty have put an end to the ideas prevailed in the medieval period. It gave rise for new states which are curious enough to assert its total independence in the new age of economic expansion by rejecting feudal notions of over lordship or papal interference. The departure from the medieval idea of law on fundamental custom and legislation lead to declare the existence of new custom. It put forth an idea that, each nation state which is a self sufficient unit recognized to be an independent legal entity having Supreme Power with virtually unlimited capacity to make new laws. This doctrine is the reassertion of the earlier theory based on the maxim 'Rex Est Imperator in Regno Suo' which depicted an idea of unacceptable unfettered legislative capacity. The new approach was essentially secular and positivist where the people were subjected to the notional subjection to over ride the natural law. The supporters of legal sovereignty intended to cut down natural law from the system of norms to a mere statement of human impulse demanding sovereign power for human society. It is also highlighted by Hobbes or Rousseau's Theory of General Will with a formal justification for the belief under inalienable sovereignty. The idea become apparent when Hume in his writing said true empiricism involves the rejection of natural law as a system of norms by arguing that validity of normative rules cannot logically be treated as an objective fact as it depends on the relative view point of those who apply them. On the other hand, positive law as the law of the state is ascertainable and valid without regard to subjective considerations separating from morals even it corresponds in many respects to current moral standards subjected to their influence. The term 'positivism is depicted by professor Hart as below

1. Laws are commands. This is associated by two founders of British Positivism, Bentham and his disciple Austin.

2. The analysis of legal concept is worth pursuing, distinct from sociological and historical inquiries, distinct from critical evaluation.

3. Decisions can be deduced logically from predetermined rules without recourse to social aims, policy or morality.

4. Moral judgments cannot be established or defended by rational argument, evidence or proof.

5. The law as it is actually laid down, positivism has to be kept separate from the law that ought to be. It may spring from a love of order, which aims at the clarification of legal conceptions and their orderly presentation. To insist that 'what the law is' is one question, 'what the law ought to be'

Positivism flourishes in stable social conditions with the difficulties of maintaining a rigid separation between 'what is' and 'what ought to be' are only projected to the forefront when conditions are in turmoil. Bentham and Austin represented the intellectual reactions against naturalism and a love, order and precision. Both were campaigner for reform but Austin insisted that prior to reform there has to be a thorough-going clarification of the law. Whether a separation between the 'is' and the 'ought' is tenable or not a debatable issue to presume in several occasions. The analysis of 'Duty' shows that law consists of prescriptive patterns of behavior, i.e. models of conduct to which people ought to confirm upon which their actual behavior is judged. Therefore, the 'is', which positivists are anxious to preserve is largely composed of 'oughts'. Natural lawyers would assert that a proposition 
is 'law' not merely because it satisfies some formal requirement but by virtue of an additional minimum moral content. Hence an immoral rule cannot become 'law' however much it may satisfy formal requirements [6]. Even where there is a rule of law, its application blurs the line between the 'is' and the 'ought'. Precedent, statutory interpretation, values and rules are occasionally shaped and reshaped so as to yield the desired conclusion.

\section{PROPOSITION ON UTILITARIANISM :}

The Utilitarian legacy proposed by Jeremy Bentham, J.S. Mill, James Mill and Henry Sidqwick facilitated the development of British imperialism and also provided a basis for the racial discourse for the nineteenth century [7]. Analytical positivism in Britain is associated with Jermy Bentham (1748-1832) \& John Austin (1790-1859). In contrast John Stuart Mill proposed that cultural, spiritual and intellectual pleasures are greater in value over the physical pleasures [8]. Bentham being the forerunner of analytical method in England, he became the intellectual god father for Austin. Theory of Analytical Positivism created a new era in the history of legal thoughts. He was averse to natural law and metaphysical historical jurisprudence. He classifies Jurisprudence into two categories, firstly expository dealing with law and censorial dealing with law as it ought to be. As a legal positivist, he laid foundation for analytical jurisprudence distinguishing it from censorial jurisprudence. As a legal reformer who is interested in the reform of law he stressed on the evaluation aspects of law based on the doctrine of utility to which law ought to confirm calling it to be the science of legislation or censorial jurisprudence. Mankind was exposed to conflicting moralities of either legitimately choosing to follow or rejecting such laws. In the cases when natural law is violated, some scientific or rational standards shall be found out by considering utility of each law. Bentham gave credit to Priestley being the 'first person to teach him about this sacred truth to form the principle of the greatest happiness of the greatest number. It made Bentham, the Newton of the legal and moral world by introducing principles of an experimental science. He made good attempt with the well established attack on the traditional cliché of natural law and social contracts. All the pleasures and pains which reduce human needs to a 'calculus of felicity' where different 'lots' of happiness could be estimated on the quantitative tests in order to determine the extent of utility decreed. The enterprise of law shall be founded on the fundamental social facts of Bentham's universe such as pleasure, pains, motives, sensibilities, dispositions and expectations.

(i) The Theory of Fictions: Bentham's analysis of law interprets 'real entities' where words are corresponding to some objects and 'fictional entities' where the words are not corresponding to certain objects [9]. The 'fictional entities' can be better understood in the light of 'real entities' by a process of 'Paraphrases'. For example, 'Law' is a real entity and 'act', 'rights' and 'duties' were fictional.

(ii) Concept of Law and Sovereignty: Law is defined as the collection of signs and declarations formed or adopted by the Sovereign of the State to regulate the conduct of persons or class of persons who are liable or subjected to such power. Bentham's concept of law is 'Imperative' hence creates 'mandate'. This definition is dynamic in covering laws made by the legislators, judiciary, administrative bodies, domestic orders and declaratory laws. Every law is formed off following elements.

(a) Source of Law: Every law is based on the will of the sovereign. A sovereign may be any person or combination of persons upon them the whole political community pays obedience in preference over the will of others consisting more than one body obeyed in different respects. The power of the sovereign is indefinite unless limited by expressed conventions, religious or political motives. A Sovereign may conceive laws which are personally issued by him or can adopt laws which are previously issued by the former sovereign or subordinate authorities and even laws which may be issued in future by the subordinate authorities.

(b) Subjects: It includes the persons and things which are active, passive, direct or indirect by nature.

(c) Objects: Law being the 'real entity' need to be reduced into factual basis creating situations recognized to be the 'objects' in each individual law. An act may originate in person, but it shall end with any person or thing. All laws shall regulate conduct positively or negatively by imposing duties or granting permissions respectively. 
(d) Extent: The coverage of any law includes direct or indirect extents. The direct extent implies about the coverage of any law over any portion of land along by stating its termination against any actor or things present in other areas. The indirect extent keeps the relation of any actor or things in spite of certain boundaries. For example, The law shall have direct extent upon any actor who was at certain place at the time of commission of any act coming under its preview.

(e) Aspects: Every law consist 'directives' which specify the will of the sovereign over any situation and 'sanctions' to highlight upon the force of law. Will of the Sovereign includes command, prohibitions, permission and omission in any situation. Permutations of these aspects of the sovereign's will comprehend the whole range of law.

(f) Force of Law \& Sanction: The law is dependent on motives for obedience. The Sovereign's will upon any situation becomes law only with the required sanctions in the form of physical, political, religious and moral motivations. It may also include sanctions in the form of punishment and rewards. Regulation of conduct and seeking stipulation over sanctions from the people will create different circumstances hence requires separate laws in these regards.

(g) Remedial Appendages: As Sanctions are provided through subsidiary laws, hence Sanctions themselves require a further set of subsidiary laws addressing to judge the curtailment of evil in each case.

(h) Expression: Even though the will of the Sovereign can be expressed in different ways but it needs to be complete. In all cases where the matter regulated coincide with the existing law, the judge shall adopt a literal interpretation and when the expression of law is incomplete, the judge may adopt liberal interpretation. People expect the law need to be complete not only in expression but also in terms of connection and design in order to get ridden from the judge made laws.

\section{INDIVIDUALITY OR COMPLETENESS OF LAW :}

Completeness of any law which is also known as the individuality of the law can be determined on the basis of following elements [10].

(i) Integrity: The law should express actual will of the legislation after considering the existing mutual relation and dependencies between the existing laws in random without deviations. If the law does not go far enough, it becomes incomplete with respect to amplitude or if it goes too far making it incomplete with respect to discrimination. Judicial interpretations are permitted depending upon the completeness of the laws. Interpretation becomes strict when the will attributed to the legislator is really entertained by the court or interpretation becomes liberal when the will attributed by the legislator has inadvertently failed to entertained by the courts.

(ii) Unity: It depends upon the objectivity in the species of the act. Different species of the act are designated in the form of wording dictated by convenience. Every new situation arising out an act will become the object for a separate law which differentiates its unity and integrity. One species of an act may give rise to only one offence. As the laws of contract or property neither impose duties nor grant permissions it may not become laws by itself but becomes the part of other complex laws which are set out on their own for convenience.

\section{ANALYSIS AND DISCUSSION :}

(i) Natural Law is Non Sense on Silts: Bentham criticized natural law and law of equity to be the 'silt non-sense' with silly ideas. Being a practical reformer, he strongly believed in social progress hence treated natural law with little respect. He also condemned common law as 'mock-law', 'sham law', 'quasi law' a mischievous delusion. He proposed that within the system of general rules, the common law is a thing which is merely imaginary. Law is made up of commands of the supreme power in a politically organized society. He believed that the legal rules can be tested with the superior principle of utility which approves every action, as per the tendency of its occurrence by augmenting or diminishing the happiness of the party by dethroning natural law. He introduced calculus of pleasure and pain in his theory of legal and social reforms which can be used to measure law like other things. By inventing the principle of greatest good to the greatest number Bentham has been recognized as the Newton of the legal and moral world. Under Bentham's legal philosophy of 'Utilitarian Individualism' the function of law is to emancipate the individual from the bondage and 
restraint on his freedom who shall look after their welfare by themselves. He supported 'laissez faire' principle, pleaded for codification, condemned judge made law and customs etc.

(ii) Analysis of Sanctions: Sanctions [11] are not original by itself but are highly derivative but, the correlation among different types of sanctions and policy guidance is highly original which deserve close examination. Sanction is the 'Pain or Pleasure' attached to any law, classified into physical, moral, legal or political and religious classes. All the 'pleasures and pains' expected in the ordinary course of nature without human intervention are physical sanctions. Moral sanctions are the pain and pleasures expected from the action of our fellow men in terms of their spontaneous dispositions with friendship, hatred, esteem or contempt also known as popular sanctions. Hence, our opinions, sympathy, dispositions, images of honour may be highly moral or immoral as it is accompanied by high moral force. Legal or political sanctions are the pleasures and pains expected from the action of the magistrate in virtue of the law or legislative decisions which are the products of political processes that could be forgotten in any analysis of legal sanctions. Pleasures and pains arising from the religious orientation which includes orientation of the actor towards some super natural entity are known as religious sanctions.

(iii) Law \& Public Opinion: Bentham devotes considerable attention to the popular sanction especially public opinion in relation to legal sanction. The legislator must provide necessary conditions for articulation and molding of public opinion [12]. Freedom of press and publicity of legal and administrative actions are the crucial pre conditions for forming strong public opinion. Unless law protects the freedom of press, public opinion cannot grow. Enlightened public opinion may generate popular sanctions which may guide for effective implementation of laws. Public opinion partly generated by free press is indifferent or hostile to a law hence, legislator has to follow the art of guiding public opinion. Even though Bentham focused on unpopular punishments, his analysis connected law, public opinion and legitimacy of the law maker. The popular sanction may weaken or nullify the legal sanctions but a careful analysis of correlations between these two is not worked out.

(iv) Law \& Social Control: The law always should provide indirect means to prevent offences through the application of theory of social control [13]. In order to exercise social control through law the application of direct or indirect 'influence of law' over will, knowledge and power at all level is required to bring behavior consonant with the norms.

(v) Law \& Expectations: The notion of expectation in the form of security plays an important role in the theory which is the paramount end of law. There is no security without the existence of law and even cannot pursue values of subsistence, abundance and equality. An expectation is the belief which endows the people with the power of establishing a general plan of conduct to ensure the successive instants throughout the life. Law along with ministering the expectations of the people shall exercise control over the expectations. Those laws having familiarity, consistency, methodical, executable and loyal in interpreting the will of the legislator can control the expectations. Each one of these ideal conditions of good law remains pressingly relevant in a world in the twenty first century.

(vi) Law \& Social Change: It is difficult to use legislation as an instrument for revolutionary changes such as bringing equality in possessions by law as it would be exorbitant exercise over the face of utility. Most probably, radical equality is sought and maintained through violence. People keeps expectations on their fellowmen, groups and government with an aim to enjoy peaceful life, immunity from bodily and mental harm by satisfying their basic needs. Beyond the baseline of common expectations, there arise heterogeneity in the expectations of people towards others, law and government. The controversial elements of 'free and unfree', 'majority and minority', religion, class and colour may provide poor guidance to the legislator about general course of expectations.

\section{UTILITARIAN INDIVIDUALISM (FREE WILL THEORIES) :}

The Utilitarian outlook by Bentham is proposed in his work 'Introduction to the Principles of Morals and Legislation' where he explains about 'Principle of Utility' as a value of law where people are governed through 'Pleasure and Pain'. Hence the Utility becomes the Calculus of Pleasure and Pain. Bentham has borrowed this principle from Hume. The application of principle of utility shall promote greatest happiness to greatest number by approving or disapproving any action through increased or diminishing happiness. Utility means the property of any object which produce benefit, 
advantage, pleasure, happiness or to prevent the happening of mischief, pain, evil or unhappiness to the community at large or individuals in particular. The aim of law is to maximize happiness for each individual which intern result in creating happiness for all. Pleasure connotes an emotional attitude of approval and pain of disapproval. Pleasure includes pleasure of sense, pleasure of wealth, pleasure of skill, pleasure of amity, good name, power, piety, memory, imagination, expectation, relief, association etc. Similarly, there exists pain of privation, sense, awkwardness, amity, ill name, piety, benevolence, malevolence, memory, imagination, expectation, association etc. Bentham regards the sources of pleasure and pain as 'sanctions' derived from the Latin word 'Sanctio' which means the act of binding. There are four types of sanctions namely physical, political, moral and religious. The law should not guarantee the selfish desires of individual but consciously secure the common good which is the object of the legislator and foundation of this reasoning. The public good can be achieved by balancing individual interest with communal welfare called to be 'Felicific Calculus'. The conscious of the people should be trained in such a way that they learn to find pleasure in ways which are not anti social. The laws should make anti social behaviours unprofitable by making it to be the source for pain rather than pleasure by providing punishments based on the judgment of consequences. Legislative logic shall be based on cost benefit analysis as directed under the principle of utility. Every law is a coercive attack on liberty hence justified with sufficient and specific reasons by hunting out all err by ruthless analysis. Rejection and replacement of natural law and subjective values with standards of human advantages, pleasures and satisfactions has provided insufficient substitute for ethics or aesthetics. Ironically, this emphasis has created modern collective welfare state [14]. Bentham has distinguished between the sciences of legislation from expository jurisprudence. The science of legislation was a branch of morals upon which people's action is directed by rules against the private morals of individuals.

\section{CRITICISMS :}

The Social utility shall be defined in terms of individual preferences based on moral value judgments rather than on hedonistic or utilitarian terms [15]. Friedman highlighted the following arguments against Bentham's Theory

1. It is difficult to understand the transmission of subjective criterion of 'pleasure and pain' into objective one. As Pleasure connotes an emotional attitude of approval, pain of disapproval judging an action according to the pleasure-pain criteria is possible by judging its subjectively.

2. The consequences of pleasure or pain of an action may well be indefinite in time or unforeseeable; it may give rise to immediate pain with a promise of pleasure or vice versa. These factors of time and uncertainty render assessment virtually impossible.

3. It is not easy to see how the happiness of the majority increases the happiness of society as a whole.

4. In truth many actions are done unthinkingly or from habit and pleasure and pain come as often incidents to other actions.

5. There exists a confused between causes of action and reason for action.

6. He seems to have assumed that laws could be made to operate on single principle of utility, which as evident in modern times, is an unfounded belief.

7. He did not solve satisfactorily the problem of how such balancing of individual interest with communal welfare can be achieved.

\section{CONCLUSION :}

Overall Theory is found to be refreshing, exciting and relevant even today. The importance of this theory stands still until injustice or evils of world could not provide resource for better human future [16]. Bentham developed liberal theory of justice based on egalitarian principles in order to secure the life of the people in cooperation with each other [17]. This theory establish the superiority of legislation over 'natural law', 'custom' and 'common law' in the form of political action in the modern state. The theory exposed the character of law in the modern state. The theory is an attempt to liberate legislation from prejudice and instinct on scientific basis through the principle of utility 
[18]. The transition from the peculiar brand of natural law doctrine from the work of Blackstone to the rigorous positivism of Bentham represents major developments in the history of modern legal theory. According to John D Finch legal positivism and legal theory as a science of investigation are distinct from the art of rational conjecture. Bentham laid the foundations of this new approach, but far from containing the solution to problems involving the nature of positive law, his work was only the beginning of a very long and varied series of debates, which are still going on today. Modern economic theory is based on utilitarian philosophies but do not focus on the aspect of utility in every segment of its application [19]. Negative Utilitarianism will differ only when the people start accepting the sufferings by disregarding the opportunities for increasing the pleasure in their lives [20].

\section{REFERENCES :}

[1] Charles Howard Mcilwain., (1932). 'The Growth of Political Thought in the West', The Macmillan Company, New York, Set up \& Electrotyped by J.S. Cushing Co., Printed in the United States of America, Berwick \& Smith Co, p. 268.

[2] David Hume., (1978). ‘A Treatise of Human Nature’, (Ed.), P.H. Nidditch \& Selby-Bigge, Oxford University Press, pp. 516-534.

[3] Merton Robert King., (1968). 'Theory \& Social Structure', Free Press, New York, Enlarged Edition, pp. 8-34.

[4] Julius Stone, (1968). 'Human Law and Human Justice', Stanford University Press, First Edition, pp. 139-142.

[5] Ehrlich E, Ziegert K., (2001). 'Fundamental Principles of the Sociology of Law, Routledge, New York First Edition, ISBN: 9781351518352, pp. 206.

[6] Filani Vs. Government of Punjab, 1972, P.L.D.S Ct, 139 (Pakistan).

[7] John C Harsanyi., (1977). Rule Utilitarianism and Decision Theory. Erkenntnis, 11(1), 25-53.

[8] Mill, J., (1968). Utilitarianism, Liberty \& Representative Government. JM Dent and Sons, London, 16.

[9] Myneni S.R., (2013). Jurisprudence (Legal Theory). Asia Law House, Second Edition, 426431,490-495.

[10] Lord Lloyd, Hampstead., 'Introduction to Jurisprudence’, Stevens \& Sons Ltd, London, 170-179.

[11] Upendra Baxi., (1986). 'Bentham’s Theory of Legislation’, Tripathi N. M. Pvt. Ltd, Revised \& Enlarged Edition., Bombay, $\mathrm{x}$-xxxii.

[12] Dias R.W.M., (1994). 'Jurisprudence’, Aditya Books Pvt. Ltd, New Delhi, 229-230.

[13] Upendra Baxi., (1986). Bentham's Theory of Legislation. Tripathi N. M. Pvt. Ltd, Revised \& Enlarged Edition., Bombay pp. $\mathrm{x}$-xxxii.

[14] Lloyd D., (1959). 'Law of Associations', (Ed.) Ginsburg M, Law \& Opinion in England in the Twentieth Century. Stevens, 99-115.

[15] John C Harsanyi., (1977). 'Rule Utilitarianism \& Decision Theory’, Erkenntnis, 11(1), 25-53.

[16] Lawrence L Martin., (1997). Jeremy Bentham: Utilitarianism, Public Policy and the Administrative State. Journal of Management History, 3(3), 272-282. https://doi.org/10.1108/13552529710181622.

[17] Peter J. Cain., (2011). Bentham \& The Development of the British Critique of Colonialism. Utilitas, 23 (1), 1-24.

[18] Afschin Gandjour., (2007). Is it Rational to Pursue Utilitarianism?. Ethical Perspectives: Journal of the European Ethics Network, 14(2), 139-158. 
[19] Tom Warke., (2000). Classical Utilitarianism and the Methodology of Determinate Choice in Economies \& in Ethics. Journal of Economic Methodology, 7(3), 373-394.

[20] Afschin Gandjour \& Karl Wilhelm Leuterbach., (2003). Utilitarian Theories Reconsidered: Common Misconceptions More Recent Developments and Health Policy Implications. Health Care Analysis, 11(3), 229-244. 